
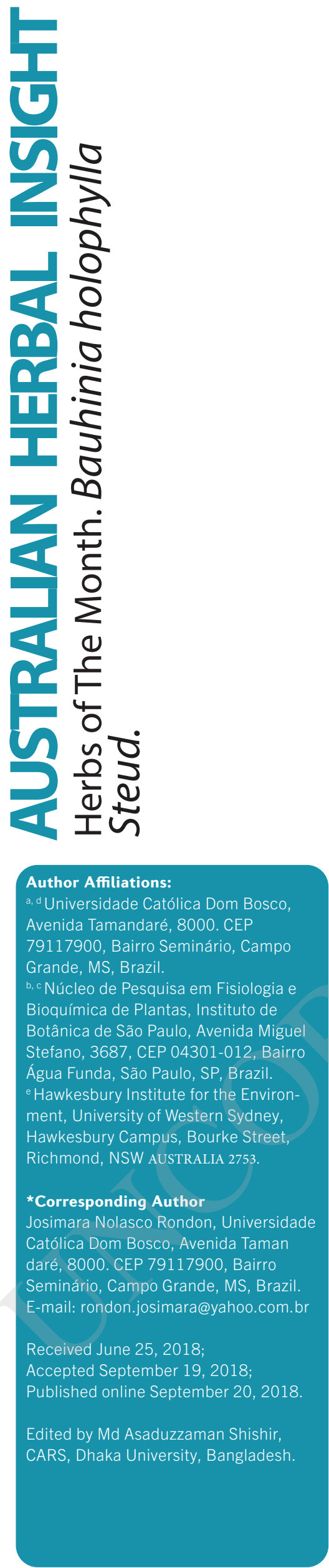

\title{
Phenology of Bauhinia holophylla Steud.
}

\author{
Josimara Nolasco Rondon ${ }^{*}$, Marcos Pereira Marinho Aidar ${ }^{b}$, Lilian \\ Beatriz Penteado Zaidan ${ }^{b, c}$, Francilina Araujo Costa ${ }^{d}$, Md Shamsuddin \\ Sultan Khan
}

\begin{abstract}
Xylopodium is a long and hard vegetative organ of the Bauhinia holophylla. This part is rich in xylem parenchyma to protect itself from heat and drought. Seeds can loss viability after a month-long storage due to the dry effect in the soil. Such storage problems for a long time usually reduce the plantation activity (seedlings) of plant species. Therefore, the objective of this study is to investigate the seedlings behavior of B. holophylla in a particular soil type and photoperiod. Germination experiments were conducted at gradient temperatures i.e. 20 to $35^{\circ} \mathrm{C}$ with $5{ }^{\circ} \mathrm{C}$ intervals and the plant growth was evaluated with photoperiods of 8 , 12,16 and $20 \mathrm{hr}$. Seedlings were evaluated with photoperiods of 16 and $20 \mathrm{hr}$ which showed significantly longer stem diameter, more leaf number and dry mass weight than those in other growth conditions. The germination period of the seeds with $25{ }^{\circ} \mathrm{C}$ was longer in comparison to other temperatures. The germination activity of this plant was similar both in light and dark conditions. At $30^{\circ} \mathrm{C}$, light, as a factor, was found to cause no significant difference in the germination. This result demonstrated the growth of the plant with long photoperiod and role of xylopodium activity.
\end{abstract}

Key words: seed; plant; Photoperiod; Savannas; Xylopodium

\section{Introduction}

Seed growth needs proper nutrition from plant during the reproduction process. Seed reserves sufficient nutrition and food for plant development at germination stage (HELENURM, SCHAAL 1996, CORBET, 1998). The study of seed germination is important to determine the management information of the plant species for conservation and economical value (MELO et al., 1998). Also, photoperiod influences the dormancy, flowering, tuberization and abscission of the plant growth in semi-dry season. The tropical plants may not influence always due to heavy rainfall for growth of plant (STUBBLEBINE et al., 1978). However, photoperiod is important factor for flowering and sexual reproduction of the plants through cross pollination (THOMAS; VINCE PRUE, 1997). The study of photoperiod in controlled light shows that length of day may affect the plant growth (KLEIN et al., 1996; ZAIDAN; FELIPPE 1994).

The genus Bauhinia (Fabaceae-Caesalpinoideae), consists of 250 species found in America, Africa, Asia and Oceania. It is widely known as pata-de-vaca. Bauhinia holophylla Steud is found in Brazil. Its height is 0.4 meters to 4 meters in semi deciduous seasonal forest. The roots are long and hard with xylopodium to survive in hot and dry condition.

The objective of this study was to investigate the reproduction of $B$. holophylla using seed and xylopod and to determine the role of photoperiod in influencing the formation of xylopodium in controlled greenhouse and soil conditions. 


\section{Materials and Methods}

Seeds of fruit were collected at the Mogi Guaçu Biological Reservation center. The study was conducted in (RBEE) (Martin Prado Júnior, São Paulo) (MANTOVANI; MARTINS, 1983). To evaluate the germination and photoperiod effect, 30 seeds were placed in six petri dishes $(9.0$ $\mathrm{cm}$ in diameter), containing filter paper moistened with distilled water. Petri dishes with seeds were placed into the germination chamber (BOD) with light conditions (160 $\mathrm{W})$, relative humidity $( \pm 80)$ and continuous temperatures $\left(20^{\circ} \mathrm{C}\right.$, $25^{\circ} \mathrm{C}, 30^{\circ} \mathrm{C}, 35^{\circ} \mathrm{C}$ ) under the white and dark light. Germination were observed every day. The growth of roots is considered as the germination of seed.

The germination $(G)$ was calculated by the method described by Labouriau (1983), the rate of germination (GSI) by Ferreira Borghetti (2004) for the study with 30 days. After 3 months, the germinated seeds were placed in a container with grassy soil $(2.5 \mathrm{~L})$ and treated with different photoperiod for $8,12,16$ and $20 \mathrm{~h}$. After that the seeds were placed separately in bright light and fluorescent light chamber with $3.5 \mathrm{~mol}$ photons $\mathrm{m}^{-2} \mathrm{~s}^{-1} \quad$ (RUGGIERO, ZAIDAN 1997, RONDON, 2006; ZAIDAN; CARREIRA, 2008). The height, diameter, number of stem leaves were considered as the growth of plant at each month. The plants were collected after 10 months according to stem, leaves and root and placed in a plastic bag to dry with $60^{\circ} \mathrm{C}$. After 4 months, the plants were weighed to determine the weight.

\section{Statistical analysis}

All data were analyzed using one way ANOVA.

\section{Results}

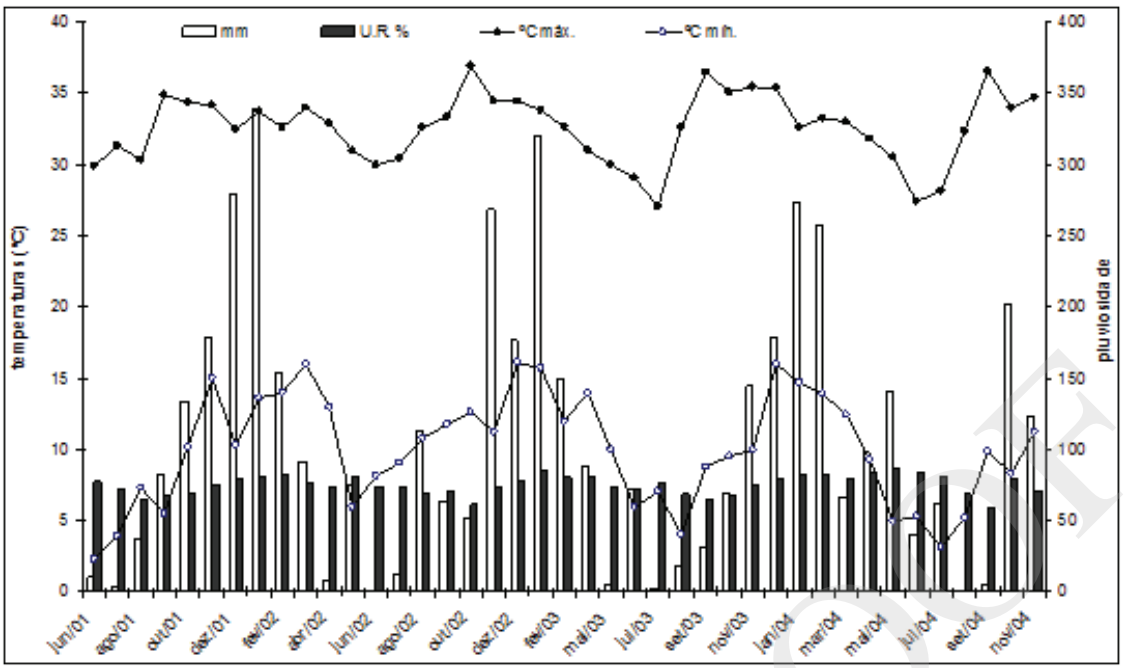

Figure 1 Climatic data obtained from Moji Guaçu Biological Reservation center and experimental meteorological place, Moji Guaçu, SP, during the study period.

Figure 1 shows the data of temperature, humidity and rainfall in the RBEE of Moji Guaçu from June to November 2017, when experiments and field observations were made.

The rain is started in August and September, and the heavy rainfall was observed in December and January. This period considered as the beginning of plant growth time. The dry season was considered as low temperatures and low rainfall in May, June and July in RBEE in Moji Guaçu.

After 10 months of daily photoperiod treatments, it was observed that the stem length and the number of leaves of plants were 16 to 20 hours long in compared to the plants treated with 8 and 12 hours (Table $1)$.

Plants were grown with photoperiod of 16 and 20 hours which showed high values of 0.26 and $0.38 \mathrm{~mm}$ of diameter, respectively. The diameter and number of leaves of plant were not significantly different at 8 and 12 h photoperiod time (Table 1). Plants exposed to 16 and $20 \mathrm{~h}$ photoperiod treatments showed 4 times more leaves than in plants exposed to 8 and 12 hour photoperiods (Table 1). The dry weight of different parts of the plant was higher in the plants kept in the photoperiod of $20 \mathrm{~h}$, which values of dry mass (stem + root) were $700 \mathrm{~g}$ and $1600 \mathrm{~g}$, respectively (Figure 2 ). The dry mass ratio of shoot and ground was higher in 16 and $20 \mathrm{~h}$ photoperiod treatments (Figure 2).

The results showed the significant difference (Tukey 5\%) among the number of healthy seeds (66.9\%), predated (13.7\%) and aborted (19.4\%) seeds.

\section{Discussion}

In the present study, it was observed that the photosynthesis of the plants showed a greater influence in plant growth for photoperiod (RONDON et al., 2006). The effect of photosynthesis was also observed in B. holophylla plants with $20 \mathrm{~h}$ photoperiod treatment which showed high dry mass in compared to the other parts with different photoperiod. $B$ holophylla of 60 and 210 days of age were placed in continuous light showed high number of leaves and dry mass than B. holophylla treated with shadow.

Diplosodon virgatus Pohl. (Lythraceae), a sub-forest species grown in the savanna, showed that the growth and flowering behavior with 12 and $16 \mathrm{~h}$ treatments were significantly different 
Table 1| Table 1. Growth of Bauhinia holophylla seedlings behavior at different photoperiod treatments for 10 months. The degree of results are shown with capital and small letters.

\begin{tabular}{|l|l|l|l|}
\hline $\begin{array}{l}\text { Photoperiod } \\
\text { (hours) }\end{array}$ & heigh $(\mathrm{cm})$ & Diameter $(\mathrm{mm})$ & Leaves number \\
\hline 08 & $4.0 \mathrm{C}$ & $0.13 \mathrm{~b}$ & $3 \mathrm{~b}$ \\
\hline 12 & $8.0 \mathrm{~B}$ & $0.14 \mathrm{~b}$ & $4 \mathrm{~b}$ \\
\hline 16 & $15.0 \mathrm{~A}$ & $0.26 \mathrm{a}$ & $10 \mathrm{a}$ \\
\hline 20 & $20.0 \mathrm{~A}$ & $0.38 \mathrm{a}$ & $12 \mathrm{a}$ \\
\hline
\end{tabular}

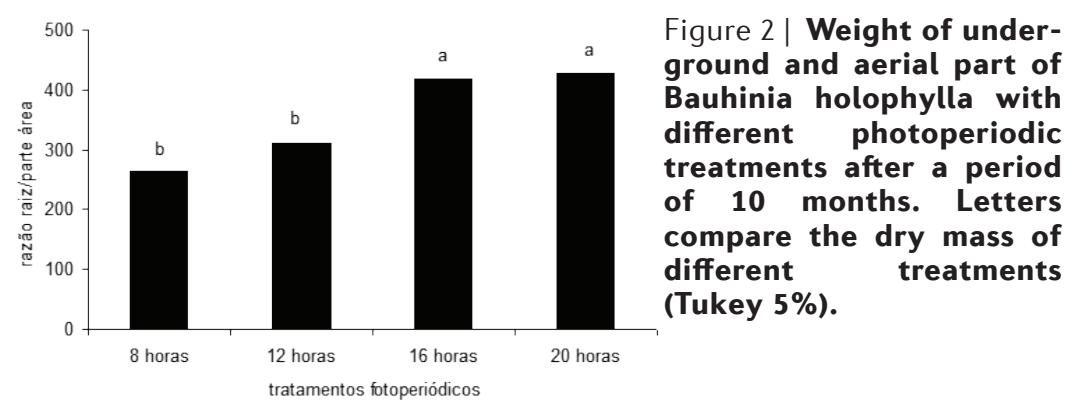

from short photoperiods. This result showed a long-day flowering behavior of the plant (CESARINO et al., 1998), which supports the results of B. holophylla. The growth of xylopodium was observed in one-month old B. holophylla with long photoperiods. However, similar results were observed for young $B$.

Furthermore, B. holophylla seeds treated with chemicals for 12 minutes shows that the germination is high and constant at $27^{\circ} \mathrm{C}$. In addition, this showed no difference due to light. So, chemical treatment can be standardize method to improve the germination process.

However, B. holophylla seeds have no dormancy behavior which is a common feature of legume species (POPINIGIS, 1977; LOPES MATHEUS, 2008).

The B. holophylla seed is kind of food for the Coleoptera Gibbobruchus cavillator (Fahraeus). So, partially eaten or damaged seeds and cotyledons do not conatin starch, sugars and other nutrition such as galactose, glucose and arabinose constituents of the endosperm which is important for germination. These sugars are the energy sources for the germination and development of the holophylla with controlled photoperiod conditions which could be comparable to D. virgatus with long day photoperiod. B. variegata L., an exotic species, grown in four photoperiodic treatments showed higher growth in long-day photoperiodic treatments than B. holophylla (RON DON, 2006). Despite photoperiodic treatment, the leaves were usually better length in long days. Number of leaves are increased due to long photoperiod and is useful for the plant growth as better photosynthesis. Thus, photosynthesis is important to increase the number of leaves and thereby increasing the dry mass.

The seedling behavior of $B$. holophylla did not show any significant difference for germination due to photoperiod and temperature. However, the germination rate was higher at $25^{\circ} \mathrm{C}$ in dark and constant light conditions. Therefore, the light and temperature $\left(25^{\circ} \mathrm{C}\right.$ and $\left.30^{\circ} \mathrm{C}\right)$ have no effect for the germination of seed in savanna due to less interaction between seed and soil and this is dependent on only on temperature. Felippe and Silva, (1984) analyzed the germination of several species of Savanna and found that the most of plant species can germinate at the temperature of $25^{\circ} \mathrm{C}$ and $30^{\circ} \mathrm{C}$. Although the number of seeds of $B$. holophylla is high, the damaged seeds shows low production in savanna. This result may be due to absence of cotyledon seedlings $B$. holophylla. The endosperm cell wall swells after interaction with water. The cell wall of B. holophylla seeds also can swell and release galactomannan, polysaccharide, to enhance the access of water in the seed for growth and germination (BUCKERIDGE et al. ., 1995).

$B$. holophylla seeds shows a considerable amount of starch in the cotyledonary parts In biochemical studies of B. holophylla seeds at different stages of imbibition observed throughout the pre-embedding process followed by followed by germination, for up to 168 hours at $30^{\circ} \mathrm{C}$ in constant light. In our preliminary study, seeds of $B$. holophylla was considered to store for one year at room temperature $(\mathrm{N}=$ $250)$ but it is shown that $(30 \%$ of pre-dried seeds with perforation due to predatory insects (RONDON, 2006). The larva of insects were found inside the seed at the time of flowering. This seed has lateral perforations due to oxypopods in the floral hipantum in savanna.

The presence of xylopodium was also observed in Terminalia argentea L. (Ferreira et al., 1998) and B. holophylla (VAZ; MARQUETE, 1993) and other savanna species. According to Barroso et al., (1984). This part works as a reservoir through an effective adaptive activity, because it allows plants to prevent unfavorable edaphic and climatic conditions (RIZZINI, HERINGER, 1962, LABOURIAU et al. 1964). The presence of this organ favors the regrowth of the aerial part when it is damaged because of fire. Thus the growth of the aerial part of the savanna species can be able to grow again (EITEN, 1990; VAZ; MAR- 
QUETE, 1993) and other savanna species. According to Barroso et al., (1984). This part works as a reservoir through an effective adaptive activity, because it allows plants to prevent unfavorable edaphic and climatic conditions (RIZZINI, HERINGER, 1962, LABOURIAU et al. 1964). The presence of this organ favors the regrowth of the aerial part when it is damaged because of fire. Thus the growth of the aerial part of the savanna species can be able to grow again (EITEN, 1990; VAZ; MARQUETE, 1993).

B. holophylla can be grown in rough condition due to presence of starch stored in the root as a reserve source. Plant roots of $B$. holophylla shows $30 \%$ starch at three months of age.

Vegetative propagation may be considered as main factors of the growth of plant because some studies shows that some plants are grown in Roupala Montana and Itirapina Savanna, which is damaged due to fire of 18 years ago with low growth rate (MIRANDA-MELO, 2004).

\section{Conclusion}

In conclusion, B. holophylla young plants can grow from xylopodium in the savanna. xylopodium provides energy and water during the dry season, which facilitates seedlings. This mechanism in juvenile plants is not only promoted by photoperiod, but also by temperature and rainfall. Although the preaching of $B$. holophylla seeds is the main cause of the absence of seedlings, the natural regeneration of this species is due to xylopodium. In adult plants, this part ease the vegetative reproduction and survival at different photoperiod and rainfall in the savanna.

\section{Acknowledgements}

The authors are thankful to $\mathrm{CNPq}$ and Biota FAPESP to support this study.

\section{Author Contribution}

\section{Competing financial interests}

The author(s) declare no competing fnancial interests

\section{References}

BORGES, E. E.; RENA, A. B. Germinação de sementes. In:.Aguiar, I.B; PIÑA

RODRIGUES, F.C.M.; FIGLIOLIA, M.B. (Eds.), Sementes florestais tropicais, Abrates, Brasília 1993. p. 137-174

BUCKERIDGE, M. S., PANEGASSI; V. R., ROCHA; D.

C.; S. M. C. Dietrich. Seed galactomannan in the classification and evolution of the leguminosae. Phytochemistry, Grã-Bretanha, v. 38, n. 4, p. 871-875, 1995.

CESARINO, F., J. E. ARAUJO; ZAIDAN, L. B. P. 1998 Germinação de sementes ecrescimento de plantas de Diplusodon virgatus Pohl, Lythraceae. Acta Botanica Brasilica, v. 12 (supl.), p. 349-356, 1998. CORBET, S.A. Fruit and seed production in relation to pollination and resources in bluebell, Hyacinthoides non-scripta. Oecologia, v. 114, p. 349-360, 1998 FELIPPE, G. M.; SILVA, J. C. S. Estudos de germinação em espécies do savanna. Revista Brasileira de Botânica, v. 7, p. 157-163, 1984. FERREIRA, A. G.; BORGHETTI, F. Interpretação de resultados de germinação. In: FERREIRA, A. G.; BORGHETT, F. (Eds.), Germinação do Básico ao Aplicado, Artmed, Porto Alegre, 2004. p. 209-222. HELENURM, K.; SCHAAL, B. A. Genetic load, nutrient limitation, and seed production in Lupinus texensis (Fabaceae). American Journal of Botany, v. 83, p. 1585-1595, 1996

KLEIN, A. L.; ZAIDAN, B. P.; FELIPPE, G. M Interaction between soil and photoperiod on development of Bidens gardneri Baker (Asteraceae), a herbaceous species from the Brazilian savanna. Revista Brasileira de Botânica, v. 19, p. 1-15, 1996. LABORIAU, L.G. A. Germinação de Sementes. Secretaria Geral da organização dos Estados Americanos. Washington D.C, Estados Unidos, 1983, $174 p$

LOPES, J. C.; MATHEUS, M.T. Caracterização morfológica de sementes, plântulas e da germinação de Dimorphandra wilsonii Rizz. - Faveiro-de-wilson (Fabaceae - Caesalpinioideae). Revista Brasileira de Sementes, v. 30, n. 1, p. 96-101, 2008.

MANTOVANI, W.; MARTINS. F.R. Florística do savanna da Reserva Biológica de Moji Guaçu, SP. Acta Botanica Brasilica, v. 7, n. 1, p. 33-60, 1983.

MELO, J. T.; SILVA, J.A.; TORRES, R.A.A.; SILVEIRA, C.E.S.; CALDAS, L. S. 1998. Coleta, propagação e desenvolvimento inicial de espécies do savanna. In: SANO, S. M.; ALMEIDA, S. P. (Eds.). Savanna: Ambiente e flora. Planaltina, Embrapa, 1998. p. 195-246.

PALHARES, D., A. C. FRANCO, A. C.; ZAIDAN, L. B. P. Photosynthetic responses of Smilax goyazana (Smilacaceae). Phyton (Horn) v. 51, p. 115-132, 2011.

POPINIGIS, F. 1977. Fisiologia de sementes. Brasília: AGIPLAN, 288p

RONDON, J. N. Autoecologia de Bauhinia holophylla Steud. (Leguminosae Caesalpinoide) na Reserva Biológica e Estação Experimental de Mogi Guaçu, SP. 76 f. Tese (Doutorado/Biologia Vegetal), Universidade Estadual de Campinas, Campinas. 2006.

RONDON, J. N.; ZAIDAN, L. B. P.; DOMINGOS, M.; BARBEDO, C. J.; FIGUEIREDO-RIBEIRO, R. C. Vegetative responses to temperature and photoperiodin saplings of brazilwood (Caesalpinia echinata Lam. Leguminosae). Brazilian Journal of Plant Physiology, n. 18, p. 467-474, 2006.

RUGGIERO, P.G.C.; ZAIDAN. L.B.P. Estudos de desenvolvimento de Viguiera robusta Gardn., uma Asteraceae do Savanna. Revista Brasileira de Botânica, v. 20, p. 1-9, 1997.

SALATINO, A. Química da folha de Bauhinia holophylla (Bong.) Steudel. Boletim de Botânica, Universidade de São Paulo, n. 5, p. 43-52, 1977.

STUBBLEBINE, W.; J.M. LANGENHEIM; LINCOLN, D. Vegetative response to photoperiod in the tropical leguminous tree Hymenaea courbaril. Biotropica, n. 10, p. $18-29,1978$

THOMAS, B. Light signals and flowering. Journal of Experimental Botany, v. 57, n. 13, p. 3387-3393, 2006 THOMAS, D.; VINCE-PRUE, D. Photoperiodism in plants. London. Academic Press. 1997.

ZAIDAN, L. B. P.; FELIPPE, G.M. Flowering of savanna plants: experiments in semi- controlled environmental conditions. Flowering Newsletter, v. 18, p. 4-11, 1994. ZAIDAN, L. B. P.; CARREIRA, R. C. Seed germination in Savanna species. Brazilian Journal of Plant Physiology, n. 20, p. 167-181, 2008. 